\title{
THE GIFT OF PARTICIPATION: ON THE TRIUNE GOD AND THE CHRISTIAN MORAL LIFE
}

\author{
Robert Vosloo \\ University of the Western Cape
}

\begin{abstract}
This paper argues for an affirmation as well as a qualification of a relational understanding of the Trinity through the notion of participation. This suggests that the "analogy" between the Trinity and the Christian moral life is not merely about correspondence that requires imitation, or about the funding of the moral imagination with metaphors, images and stories, but about participation in the Triune life. This claim is developed mainly in conversation with two recent studies in trinitarian theology, namely These Three Are One by David Cunningham and Participating in God by Paul Fiddes. The paper also argues that participation in the Triune life is a participation through the Spirit. Without such a pneumatological focus - without the gift of the Spirit - the moral life is robbed of the resources that enable a life of freedom, responsibility, generous hospitality and joy. Participation is, however, not a vague "spiritual" notion, because the participation in the Triune life through the Spirit is a participation in Christ. This participation is, as suggested by Dietrich Bonhoeffer, a participation in reality. It is a participation in life.
\end{abstract}

\section{The promise of trinitarian theology for rethinking the Christian moral life}

There has been a remarkable renaissance or revival in trinitarian studies over the last few decades. It is not the intention in this paper to trace the genesis of this development or to highlight possible reasons for this revival, but rather to call attention to the promise and problems of relating the doctrine of the Trinity to the Christian moral life. Many of the recent studies in trinitarian theology have attempted consciously to relate the Trinity to Christian practice. Catherine LaCugna, for instance, writes in the introduction of her book God For Us (meaningfully subtitled The Trinity and Christian Life) that the doctrine of the Trinity "is ultimately a practical doctrine with radical consequences for Christian life."1 This concern for Christian practice is also evident in two more recent studies, namely David Cunningham's book These Three Are One (subtitled The Practice of Trinitarian Theology) and Paul Fiddes's book Participating in God (subtitled A Pastoral Doctrine of the Trinity). ${ }^{2}$ This paper is by and large a searching engagement with the latter two studies.

While the constructive proposals of the different theologians writing on the doctrine of the Trinity today lead in different directions, there does seem to be a near consensus that a

1. LaCugna, C M, God For Us, The Trinity \& Christian Life (New York, Harper San Francisco, 1991), 1. The pathos of LaCugna's book is well portrayed when she writes: "The doctrine of the Trinity is God's intimate communion with us through Jesus Christ in the Holy Spirit. As such, it is an eminently practical doctrine with far-reaching consequences for Christian life. By connecting the doctrine of the Trinity with the concrete language and images of the Bible, creeds, and liturgy, the Christian doctrine of God can be reconnected with other areas of theology, as well as to ethics, spirituality, and the life of the church" (ix).

2. Cunningham, DS, These Three Are One: The Practice of Trinitarian Theology (Oxford: Blackwell, 1998); Fiddes, P, Participating in God: A Pastoral Theology of the Trinity (Louisville: Westminster/ John Knox Press). These more explicit references to Christian practice do not mean that other studies do not aim at the Christian life, but the explicit reference does point to the conscious attempt to relate the doctrine to the Christian life. 
more relational understanding of the Triune God has enormous potential for a re-thinking of, for instance, our views on anthropology, ecclesiology and ethics. ${ }^{3}$ It is often argued that a relational understanding of the Trinity challenges the modern cult of the individual and helps us to understand ourselves not as isolated individuals, but as persons-in-relation. It furthermore seems to promise to relate identity and otherness in a way that embraces pluralism. The emphasis on relationality also fits well with certain postmodern sensibilities that shy away from fixed categories. According to many theologians a relational view of the Trinity points to a more egalitarian ecclesiology in which relationships of domination are exposed and the church is drawn to a praxis of justice. Due to the relationships in the Triune Life being self-giving and other-receiving relationships, it is also argued that a relational understanding serves as inspiration for lives of just generosity and hospitable love.

A so-called relational understanding of the Triune God, thus, seemingly holds promise to help us imagine or re-imagine God in such a way that we may view ourselves, others and creation differently. Given the challenges of the South(ern) African situation, it seems to point to matters of major importance. But, acknowledging this, the task still remains to clarify what such a relational understanding of the Triune God entails, and to reflect on how we relate such a more relational doctrine of the Trinity to the Christian (moral) life?

While these questions may seem to point in the direction of technicalities, it is of great importance to think about them in order to reflect on the moral life, not merely in terms of philosophical, psychological or sociological categories, but theologically - that means, among others things, with reference to the doctrine of God. The recent ecumenical reconsideration of the filioque controversy has to do with the recognition of a relational understanding of the Divine life. ${ }^{4}$ In this paper I would like to affirm as well as qualify such a relational understanding of the Triune God by reflection on the notion of participation.

\section{Imitation, imagination and participation}

How do we relate the doctrine of the Trinity to Christian ethics? Or stated in more personal terms: how do we relate the Triune life to the Christian life? One possible answer to this question is to argue that the Triune life serves as model for the Christian life. Though there is some possible biblical warrant for such an approach, ${ }^{5}$ it seems to be highly problematic to limit the moral life to such an ethic of imitation. Such an ethic of imitation fails to take the discontinuity between God's identity and our identities seriously. What is meant by

3. Among the many studies in trinitarian theology that make some kind of plea for a stronger relational understanding of the Trinity, and not mentioned so far in this paper, see Moltmann, J, The Trinity and the Kingdom: The Doctrine of God ((Minneapolis: Fortress Press, 1981); Boff, L, Trinity and Society (Maryknoll, NY: Orbis Books, 1988); Gunton, C, The One, The Three and the Many: God, Creation and the Culture of Modernity (Cambridge: Cambridge University Press, 1993); Jenson, R, Systematic Theology, Vol. 1: The Triune God (New York: Oxford University Press, 1997); Jüngel, E, The Doctrine of the Trinity: God's Being is in Becoming (Edinburgh: Scottish Academic Press, 1976); Elizabeth Johnson, E A, She Who Is: The Mystery of God in Feminist Theological Discourse (New York: Crossroad, 1992); Peters, T, God as Trinity: Relationality and Temporality in Divine Life (Louisville: Westminster/ John Knox Press), 1993; Torrance, A J, Persons in Communion: Trinitarian Description and Human Participation (Edinburgh: T\&T Clark, 1996); Volf, M, After Our Likeness: The Church as the Image of the Trinity (Grand Rapids: Eerdmans, 1998).

4. See, for instance, Peters, T, God As Trinity: Relationality and Temporality in Divine Life, 63. See also Schwöbel, C, Trinitarian Theology Today (Edinburgh, T\&T Clark, 1995), 4. In his contribution elsewhere in this volume, Bernd Oberdorfer also pointed to the fact that the question of the filioque is a question on the hermeneutics of trinitarian theology.

5. For instance, "You shall be holy as I am Holy" (Lev 11:44,45) and "Be perfect, therefore, as your heavenly Father is perfect" (Matt 5:48). 
"person" or "relation" within the Triune life cannot to be equated uncritically with what we understand about human personhood or relationality. Such a discontinuity points to the importance of a hermeneutical task that is marked by struggle, interpretation, ambiguity and embodiment. While an ethic of imitation does help us to find continuity between God's Triune life and our lives, its failure to deal adequately with discontinuity ultimately turns the moral life into a cold ideal or hard law. In the process it does not only fail to take seriously the complexities of being human, but also leaves insufficient room for grace and gratitude.

With regard to trinitarian theology there is a real temptation to speculate about analogies between God's inner trinitarian life and our vision for personhood, the church and society. While such attempts are rhetorically powerful, they are nevertheless theologically suspect. These cautionary remarks do not mean that we are doomed to silence with regard to the continuities between God's identity and ours, or that we can disregard biblical texts that seem to speak the language of imitation. They do, however, point to the dangers of using the notion of imitation in an uncritical way when relating the doctrine of the Triune God to the Christian moral life. ${ }^{6}$ As Christoph Schwöbel writes: "The relationship between our views of God and our views on the order of personal and social relationships is complex. It would be theologically disastrous if one criticizes the projection of certain views of the divine nature on the order of human society for its alienating effects, and then proceeded by projecting a view of desirable human relationships on the divine being."7

Given this critique of the notion of imitation, it can be argued that the notion of imagination is more adequate for making the link between the Triune life and the Christian moral life. The images, metaphor and stories of the Triune God's dealings with creation inspire Christian moral imaginations in a way that enables a different construal of the world. For some, such a link between imagination and ethics will be problematic especially for those who espouse certain modernistic ethical theories. For them, the focus on imagination will seem to be subjective, arbitrary and non-rational. These modernistic moral theories, however, have been highly criticised in recent moral discourse. ${ }^{8}$ The plea for the moral importance of the identity of the moral agent enables a broader understanding of ethics that creates the space to integrate imagination more fully into our understanding of the moral life. Such a plea for the moral importance of imagination has, among other things, the potential for a more constructive linking of goodness and beauty, or ethics and aesthetics. ${ }^{9}$

6. In his article "The Trinity Is Our Social Program" (Modern Theology 14: 3 July 1998) Miroslav Volf, in reflecting on a statement by Nicholas Federov, points to two equally unattractive options, the one consisting in seeking to imitate the Triune God with blatant disregard for the fact that we are not God and the other consisting in respecting our creaturely difference but failing our most proper human calling to be like God (404. 405). Volf continues: "Between 'copying God in all respects' and 'not copying God at all' lies the widely open space of human responsibility which consists in "copying God in some respects"' (405). Volf acknowledge that there are limits to the correspondences between the Triune God and humans. He does not believe that the doctrine of the Trinity provides as social programme, but argues that it does contain the contours of the ultimate normative end to which all social programmes should strive (406). Hence his use of the term social vision. In his book After Our Likeness: The Church as the Image of the Trinity Volf gives a more elaborate discussion of his plea that there is broken creaturely correspondences between the Triune God and humanity. See especially, 191-220.

7. Schwöbel, Trinitarian Theology Today, 11.

8. See for instance MacIntyre, A, After Virtue (Notre Dame: University of Notre Dame Press, 1981); Taylor, C, The Sources of the Self (Cambridge: Harvard University Press, 1989) and Hauerwas, S, The Peaceable Kingdom (Notre Dame: The University of Notre Dame Press, 1983).

9. For a reflection on the importance of imagination for Christian ethics, see my article "Etiek as Optiek? Oor die rol van beelde en verbeelding in die Christelike morele lewe" (NGTT, forthcoming). 
While such a link between imagination and the moral life seems of paramount importance, imagination (understood in a certain way) does seem to have limitations as a moral category. It can lead to an individualistic, disembodied view of the moral life that separates imagination from Christian practices, or point to the importance of creative genius in such a way that the isolated, autonomous self of the Enlightenment remains intact. Imagination as a moral notion certainly has value as a critique of the subject-object dichotomy of the Enlightenment, but it needs qualification.

Given the limitations of certain constructions of the notions of imitation and imagination for providing a link between the Triune life and the Christian moral life, we can ask whether the notion of participation is not a more adequate notion. The Christian moral life is not merely about imitating or imagining differently, but about participation in the life of the Triune God. Therefore the Triune life is not merely a model or inspiration, but also the source that enables a Christian moral life. This does not deny the importance of imagination, but it does qualify the faithful Christian imagination as being a participatory imagination or, put differently, an imaginative participation. Such a view of the Christian moral imagination as a participatory imagination challenges the less helpful strands of modern ethical theory and holds the potential to give a more adequate account the relationship between the doctrine of the Trinity and the Christian moral life.

This notion of participation, however, needs further explanation and qualification. The rest of this contribution involves a conversation with two recent studies that explicitly make use of the notion of participation, as well as with Dietrich Bonhoeffer, in whose work the notion of participation plays a more implicit, albeit important, role.

\section{Challenging the relational consensus: David Cunningham}

The so-called current "relational consensus" in trinitarian theology has been challenged recently by David Cunningham. Cunningham is an American theologian and the author of an award-winning book entitled Faithful Persuasion (on the theme of rhetoric). In 1998 his already mentioned book These Three are One: The Practice of Trinitarian Theology was published and in this book, as well as in a published article ${ }^{10}$ he challenges the so-called "relational consensus" by proposing a move from relationality to participation. Cunningham argues that it is difficult for us to imagine relationships without establishing the independent existence of two or more entities. This is problematic for the Three (a term that Cunningham favours for the Triune God). In God, argues Cunningham, there are not three "somethings" who "decide" to come into relation with one another, but the Three are wholly constituted by this relationality; they are "relation without remainder," or to quote Nicholas Lash, "while we 'have' relations, God is the relations that God has." "The references by many contemporary theologians to relationality still recall for him an image of three individuals. ${ }^{12}$ The problem for Cunningham is that, while these writers believe that the doctrine of the Trinity can act as a hedge between the individualism and privatisation of our modern / post-modern culture, it stills employ language that is easily co-opted into that very individualistic framework. Therefore a relational ontology does not replace an ontology of substance, but simply makes it more palatable for an audience that has become

10. Cunningham, D S, "Participation as a Trinitarian Virtue: Challenging the Current 'Relational Consensus'." Toronto Journal of Theology 1998: 14/1, 7-25.

11. Cunningham, Participation as Trinitarian Virtue, 8.

12. For Cunningham this helps to explain the popularity of the notion of persons in relation. He criticises this notion (as developed by, for instance, Catherine LaCugna and Alan Torrance) as still being captive to a substantialist ontology. 
somewhat jaded about sweeping metaphysical claims. It is clear that Cunningham is sympathetic to attempts like those of John Milbank to create a "theology without substance" (to evoke an influential two-part article by Milbank) or Jean-Luc Marion to describe a "God without Being" (to give the English title of one of Marion's books). Cunningham joins this chorus by claiming that the doctrine of the Trinity is an overcoming of ontology. Instead of underwriting an ontology of substance, "the doctrine of the Trinity helps us to understand God not as being, but as harmonious difference, superabundant donation and self-abandoning love."13

In his move away from the language of substance or ontology, Cunningham draws on the current revival of the category of virtue in moral philosophy and theological ethics. Cunningham construes virtue as naming the dispositions that God has by nature and in which we participate by grace. In the light of this Cunningham calls attention to certain "trinitarian virtues." These trinitarian virtues are characteristics of the triune God that are freely bestowed on us as gifts. In his book These Three Are One Cunningham discusses three of these "trinitarian virtues", which he calls polyphony, participation and particularity. He develops these notions at length and relates them to certain Christian practices.

I would like to call attention to the second of these trinitarian virtues, namely participation. As mentioned, Cunningham emphasises that the main point about the Three is not that they are related, but that they participate in one another to such a degree that any attempt to understand them as independent entities is undermined. For Cunningham the implication of this is that "human beings are called to understand themselves, not as 'individuals' who may (or may not) choose to enter in relationships, but rather as mutually indwelling and indwelt, and to such a degree that - echoing the indwelling of the Three all pretensions to wholly independent existence are abolished." ${ }^{14}$ Cunningham wants us not simply to value "relationality", but to think about the character of relationships. Hence the use of the notion of participation.

We need to note that Cunningham understands participation not in the sense of taking part in something, but in the sense of taking part in someone (as in the phrase "participating in the sufferings of another"). This emphasises something of the intimacy that the term wants to portray. Therefore he links the word participation to notions such as fellowship and communion (the Greek word koinonia). ${ }^{15}$ It is about mutual indwelling in which the lines between an "I" and "you" are blurred, and subject and object are understood as rhetorical categories (denoting the whence and whereof) of communication.

Cunningham's thoughts on participation lead him to discuss a term often used in trinitarian theology, namely the patristic notion of perichoresis. ${ }^{16}$ This term was originally used to describe the reciprocal participation of the two natures of Christ. The $6^{\text {th }}$ century writer called Pseudo-Cyril was probably the first to apply this term to the mutual

13. Cunningham, Participation As a Trinitarian Virtue, 9.

14. Cunningham, These Three Are One, 166.

15. It can be mentioned that while the notions of participation and communion (koinonia) are often used interchangeably, it is worthwhile to remember some historical distinctions in this regard. In his book Being as Communion the Orthodox theologian John Zizioulas asks, with reference to Origen, how participation differs from communion. Zizioulas notes that while the terms participation and communion at first sight seem to be interchangeable in the Greek Fathers, they did make a clear and deliberate distinction. Participation is used for creatures in relation with God and never for God in relationship to creatures. See Being as Communion (New York: St Vladimir's Seminary Press, 1997), 94.

16. Most notably this notion of perichoresis is reflected on in the work of Jürgen Moltmann, Leonardo Boff, Colin Gunton, Catherine LaCugna, Elizabeth Johnson, Eberhard Jüngel and Miroslav Volf. See also the influential discussion of the term by G L Prestige in his book God in Patristic Thought (London: SPCK, 1952), 282-301. 
participation within the Trinity. John of Damascus also used this notion in the $8^{\text {th }}$ century. This term took up and developed the statement of Jesus in John 14:11: "Believe me when I say that I am in the Father and the Father is in me". The term perichoresis is difficult to translate but includes connotations such as interpenetration or co-inherence. It is about the mutual indwelling of the Three, about permeation without confusion. For Cunningham this notion of perichoresis is a praiseworthy attempt to prevent the isolation and separation of the Three. He does wonder though whether this rich notion would need to play such a prominent role if we were to begin with a less individualistic portrait of the Three in the first place.

The content and pathos of Cunningham's argument can be summarised by noting his point that "the notion of a pure, isolated 'individual' is a highly disputable human construction. In God, there are no individuals; the Three dwell in the other so completely that we cannot divide them ... And so we too are called to live lives of mutual participation, in which our relationships is not something we 'have,' but are what constitutes us as human beings". ${ }^{17}$ Cunningham calls for a human paralleling of the trinitarian virtue of participation.

Cunningham's challenge to abstract relational language with regard to the triune God is in my view very important. The notion of participation does point in the direction of a stronger description of the character of the relations within God. His reflection on the notion of participation does, however, raise a few important questions.

Reading Cunningham one hears clearly the critique against the modern cult of the individual in his emphasis on the importance of dwelling in, and being indwelt by the lives of others. These attempts are praiseworthy, but one can ask whether the total move away from substantialist categories - while seemingly powerful for challenging the modern self does not leave us without resources to challenge the so-called postmodern "self". Does such a move away from absolute substance not end in a new absolute, namely that of absolute relation - one which is vulnerable to the same totalitarian tendencies?

As mentioned above, Cunningham calls for a paralleling of the trinitarian virtue of participation. While he admits that our status as creatures rules out any perfect imaging of God's internal participation and that we must not underestimate the power of the Spirit that works in us to do infinitely more that we can imagine, he does not develop this more fully. I think that Paul Fiddes's critical remark is to the point when he writes that Cunningham "deals with 'participation' almost entirely as a parallel between the participation that occurs within God's own communion and that within human society; he does not dwell on our human participation in God." 18 Does not the notion of participation require a stronger pneumatological description than the one that Cunningham supplies?

\section{Participation and pastoral experience: Paul Fiddes}

With these remarks and questions in mind we can turn to Paul Fiddes as our second conversation partner. He is a theologian from Oxford and his books include The Creative Suffering of God (1988) and The Promised End (2000). ${ }^{19}$ Like Cunningham, Fiddes uses participation as a central notion in the argument of his book Participating in God: a

17. Cunningham, These Three Are One, 169.

18. Fiddes, Participating in God, 39.

19. Fiddes., P, The Creative Suffering of God (Oxford Claredon Press, 1988); The Promised End: Eschatology in Theology and Literature (Oxford: Blackwell, 2000). Other books by Fiddes include Past Event and Present Salvation (London: Darton, Longman and Todd, 1989) and Freedom and Limit: A Dialogue between Literature and Christian Doctrine (Basingstoke: MacMillan Press, 1991). 
Pastoral Doctrine of the Trinity (2000). Fiddes describes the aim of this book as "to begin to shift our way of thinking away from the 'observational' which is characteristic of the split between subject and object in our Western culture, and to introduce the aspect of 'participation' in what is real." 20

Fiddes is also highly critical of the individualistic and privatised self, but seems to be more sensitive than most scholars about taking certain pastoral questions into consideration in his discussion of the relation between the individual and the community. He emphasises the need to "create a balance the person and the personage, between self-integrity and openness to others, between independence and dependence, and between diversity and unity." ${ }^{21}$ What then, he asks, is the place of the Christian doctrine of the Trinity (which concerns a personal God that lives in relationships) in the face of these pastoral questions?

In his reflection on this question Fiddes also rejects the strategy that urges mere imitation of the Triune God. Such a rhetorical appeal is not altogether futile for Fiddes and he notes that he also aims at a type of "trinitarian modelling." He continues, however, by commenting that an imitation of God - as a concept of God to be implemented - is not a sufficient pastoral theology and that he is aiming to complement the imitation of God with a thoroughgoing attempt to speak of participation in God as pastoral experience. ${ }^{22}$

This, argues Fiddes, has implications for the language we use about God in the sense that it cannot be observational language that describes God from the standpoint of an external perceiver. This emphasis does not point to an existentialist approach that merely appeals to experience. Instead, it implies that, "There is a way forward 'into God', which recognises both the divine mystery and the brokenness of human words in the face of God. If God has taken the initiative in self-disclosure, and we have experienced the gift of God's self-unveiling in our experience, then we are required to speak both to and about the Giver."23

Such personal language remains metaphorical and analogical, "but it has the capacity to be a language of participation, pointing to engagement in God and drawing us into such involvement." 24 The language of participation leads Fiddes to embraces Barth's language of event with regard to the being of God, but he criticises Barth's notion of "modes of being" (the term that Barth prefers to the "persons" of the Trinity). He sees this as contrary to Barth's own perception of the dynamic nature of God. Fiddes prefers to speak of "movements of relationship" (or better: movements or relationships subsisting in one event"). This is for him not the language of spectator but of participant.

What seems to me to be important in Fiddes' discussion is his bringing together a way of understanding the nature of being (ontology) with a way of knowing (epistemology) in a manner that understands the being of God as event and relationship, but only through an epistemology of participation. He writes: "Only by bringing together being as relation, and knowing as participation, will we begin to overcome the view of the human subject stemming from the Enlightenment, in which observation is the basic paradigm of knowing.",25

\footnotetext{
20. Fiddes, Participating in God, 12. In his book The Promised End Fiddes also uses the notion of (trinitarian) participation as a key category in his argument. See, for instance, 204-206; 262-288.

21. Fiddes, Participating in God, 28.

22. Fiddes, Participating in God, 29.

23. Fiddes, Participating in God, 30.

24. Fiddes, Participating in God, 33.

25. Fiddes, Participating in God, 38.
} 
It is not surprising that Fiddes also discusses the notion of perichoresis as a concept that emphasises that the language of the Trinity is not a language of observation but of participation. In his discussion of the notion Fiddes refers to the two Latin terms that were used to translate the Greek term. Circuminsessio (from circum-in-sedere, to sit around) means that one person is contained in the other, literally "seated" in another. This term stressed a state of being and was preferred by Aquinas. The second term, circumincessio (circum-incedere, to move around), is a more active word that evokes a state of doing and captures a sense of movement. This second aspect points to a metaphor that was occasionally applied to perichoresis in the Middle Ages, namely that of the divine dance. While the term perichoresis does not derive from 'dance around" (perichoreuo), it does illustrate the dynamic sense of the term.

This idea of perichoresis as divine dance is valuable for Fiddes because it fits his understanding of the divine persons as movements of relationship. It is not so much about the dancers as about the pattern of the dance itself. Fiddes admits that this metaphor of the dance did not originally take hold on Christian imaginations as a metaphor for the inner participation of the Triune God, but that it did later become a widespread image for the participation of all created beings in God. One reason why the metaphor of dance was not used frequently with regard to the divine life relates to the neo-platonic tendency to avoid movement in God. Yet this idea of a God in movement is exactly the dynamic image of God that Fiddes wants to commend for a pastoral theology. Dance, he writes, "implies a God in movement, even a God in the process of change, rather than a God whose intellectual love simply moves other things and people by their contemplation of it." ${ }^{, 26}$ This challenges the image of the dominating God whose power lies in immobility and being secure from being affected by the changing world.

Fiddes develops the notion of participation in God further with regard to questions dealing with power, prayer, suffering, forgiveness and the threat of death. In an important chapter on the Spirit of God, Fiddes refers to the images of Spirit as "wind", "breath" and "fire" as images that open up our sense of God. These images remind us of the reality that enables us not only to talk about God, but also to participate in God. The Spirit is therefore

26. Fiddes, Participating in God, 74. Fiddes gives an interesting discussion of how this metaphor of the divine dance was developed differently in the East and the West (see especially 75-81). In the East it was like a progressive dance (out from the Father and back in to the Father). Salvation is viewed as divinisation (theosis). The danger of this approach is that the Father can be viewed as the dominating partner, subordinating the other dancers, and thus sanctioning hierarchies of power. In the West the metaphor of dance is used more in the sense of a circle dance. The origin of the Trinity is not in the Father, but in the one nature of God. This holds the danger that the one nature becomes a fourth factor somehow behind the three persons, although the best theologians understood the one nature as nothing other than a perichoresis of persons. This stresses the equality, mutuality and reciprocity of the Three. This picture of symmetrical fellowship is capped by the idea in the West that the Spirit is the bond of love between the other two persons. Thus the notion of the filioque - that the Spirit proceeds from the Father and the Son. This is attractive, especially to those who fear that the idea of the monarchy of the Father does not serve sufficiently the agenda of the liberation of people from oppression and inequality. The danger of the Western notion of the circle dance is that it can become a closed circle, a self-sufficient dance. For Fiddes the progressive dance of the East makes ousia a mystery; while the circle dance can make the distinctions of the triune relations a mystery within God's inner life. For Fiddes, Augustine veers in this direction with his notion of the external actions as indistinguishable and inseparable. For Fiddes, the stress on engagement (participation) helps us to see the best of the insights of the East and the West. There are mutuality and reciprocity in God, yet we do not observe these relationships, but are drawn to share in the movements of the divine dance. The Eastern insight that the Father is the origin or source (arche) of the Son and the Spirit makes clear that the dance is not a swirling vortex of arbitrary currents. The dance may be a complex one, yet it has a pattern. There is direction to its flow (which is like the movements to and from an ultimate source). 
the "opener" or the "disturber" ${ }^{27}$ Fiddes also affirms Richard of St Victor's notion of "the Third" as necessary for love to be actualised. The Holy Spirit is the Third person who opens up relationships, "who makes us look more deeply at ourselves, at others and the society around us." ${ }^{28}$ Fiddes concludes his study, with a chapter on the incarnate God and the sacramental life, with the summarising remark that the openness to the presence of God "can be felt like the invitation to a dance, but sometimes like the raw edges of a wound". "This," he writes, "is participation in God. This is theology." 29

This short discussion on Fiddes's use of the notion of participation calls for a few additional remarks and raises some questions. Fiddes's use of "persons as relations" raises the same questions we asked with regard to Cunningham's total move away form substance to relation. Fiddes shares Cunningham's view that the "persons" (hypostases) are the relations (he sees himself as following the view of the Cappadocian Fathers in the Eastern Church who seem to see the being of God as communion or fellowship). There are therefore no persons at the end of the relations, but the "persons" are simply the relations.

What seems to me extremely valuable in Fiddes's discussion is his challenge to the subject-object dichotomy of the Enlightenment through his epistemology of participation. There is not merely participation in God, but through the Spirit human beings participate in the movements of relationship within God. This challenges the language of the spectator or observer and has important potential for affirming the moral importance of worship and Christian practices like baptism and the Eucharist.

While it will probably be unjust to say that Fiddes falls victim to a type of pantheism in his discussion of our participation in God, we certainly can ask the question whether the notion of participating in God does not need an even stronger Christological focus than Fiddes reveals in his study.$^{30}$ It is in my view very important that the notion of participation is not merely a partcipation in God in some esoteric way, but that due to a certain understanding of Christ, it is therefore a participation in reality - it is a participation in life, it is being drawn into life.

\section{Participation in Christ: Dietrich Bonhoeffer}

Towards the end of his book God the Spirit the German theologian Michael Welker describes the Spirit as the enabler that enables intimacy with God, free self-withdrawal, participation in God's glory and the enjoyment of eternal life. Welker makes the important remark that, although the Spirit draws us into the overwhelming fullness of the presence of God, "this intimacy is not to be confused with an ineffable, obscure mystical relationship whose intensity condemns us to say nothing, or whose hypercomplexity leads to diffusion or dissolution of determinate experience." ${ }^{, 31}$ This remark serves in my view as an important reminder that the description of the Christian life as participation through the Spirit is subject to dissolution in a hazy mysticism that dislocates the Christian moral life from the economy of salvation. Or, put differently: our participation in God is a participation in Christ and through the Spirit.

27. In his book The Promised End Fiddes also uses the image of the Spirit as the opener. He writes: "The movement of spirit-ness can be recognized as a continual opening up the hidden depths of relationship between the Father and Son, a deepening and diversifying of communion that makes it apt to 'appropriate' fellowship to the Spirit, while not reserving the creating of fellowship entirely to this relation" (270).

28. Fiddes, Participation in God, 267.

29. Fiddes, Participation in God, 302.

30. It needs to be said that Fiddes's emphasis in the last chapter of his book on bodies, the body of Christ, and the Eucharist points away from some kind of esoteric participation in God that is separated from "reality".

31. Welker, M, God the Spirit (Minneapolis: Fortress Press, 1994), 331. 
The notion of participation in Christ plays an important role in the theology of Dietrich Bonhoeffer. In his second Berlin dissertation Act and Being he writes about "being in Christ". ${ }^{32}$ In his Ethics Bonhoeffer uses the notion of participation frequently. In the section on Christ, Reality and the Good Bonhoeffer, for instance, writes: "The question of good becomes the participation in the divine reality which is revealed in Christ." 33 A few pages further we read: "In Christ we are offered the possibility to partake in the reality of God and the reality of the world, but not in the one without the other." 34 Bonhoeffer's use of participation in Christ offers a few important perspectives that must be kept in mind if we are to use the notion of participation with regard to the Christian moral life.

- Participation in reality is, as seen from Bonhoeffer's remarks quoted above, a participation in the reality of God and the reality of the world. This makes it clear that Christian moral life is not an esoteric life, but an earthly life that asks for an earthly holiness. Our participating in the reality of God in Christ has everything to do with this earth and this life. In the prison letter of 5 December 1943 Bonhoeffer remarks: "My thought and feelings seem to be getting more and more like those of the Old Testament ... it is only when one loves life and the earth so much that without them everything seems to be over that one may believe in the resurrection and the new world." ${ }^{35}$ And later on he again talks talk of the "earthly beauty" as "the only kind of beauty that really appeals to me." 36

- As participation in Christ, the Christian life is furthermore a sharing in the suffering of Christ. It testifies to, in the words of Bonhoeffer's famous paragraph, "a view from below": "We have for once learnt to see the great events of world history from below, from the perspective of the outcast, the suspects, the maltreated, the powerless, the oppressed, the reviled - in short from the perspective of those who suffer.",37

These few cursory remarks on Bonhoeffer's use of the notion of participation serve in my view as a helpful reminder and an important challenge not to use the notion of participation in any vague esoteric sense that separates it from notions like discipleship and responsibility. It can be argued that Bonhoeffer's Christological description of the moral life needs a clearer trinitarian context ${ }^{38}$, but his (in a way understandable) Christological focus serves as reminder to describe the moral life not merely as participation through the Spirit, but indeed as participation in Christ and through the Spirit. ${ }^{39}$

32. Bonhoeffer, D, Act and Being (Minneapolis: Fortress Press, 1996). See especially 150-161.

33. Bonhoeffer, Ethics (London: SCM Press), 163.

34. Bonhoeffer, Ethics, 167.

35. Dietrich Bonhoeffer, Letters and Papers from Prison (London, SCM Press, 1953), 157.

36. Bonhoeffer, Letters and Papers, 239.

37. See Bonhoeffer, Letters and Papers, 17.

38. As argued by Charles Marsh in his book Reclaiming Dietrich Bonhoeffer (New York: Oxford University Press, 1994).

39. While there may be enough reason to speak of participation in Christ and through the Spirit, it is certainly also possible to follow the doxological pattern of St Basil the Great in his treatise On the Holy Spirit and speak of participation in the glory of the Father, through (dia) the Son in (en) the Spirit. For a very interesting discussion of this doxological pattern, see Geoffrey Wainwright's article "Trinitarian Worship" in Kimel, A F (ed), Speaking the Christian God (Grand Rapids: Eerdmans, 1992), 209-221. The point is, however, that it is important to hold to a Christological and a pneumatological focus when using the notion of participation as a way to describe relations in God and our participation in that participation. 


\section{The participatory imagination and the Christian moral life}

Within South African society there is evidence of a growing social apathy (a type of aparticipation). This social apathy results from and contributes to the so-called crisis of morality in our society. Such a social apathy has many sources, but one of them is certainly related to the increasing dominance of the view of the self as an isolated individual. This understanding of human personhood needs to be challenged in a responsible way if we are to face moral problems seriously. In my view, a re-imagining of God in which we see God not as isolated individuals or as a lonely monarch can inspire our imaginations to view ourselves, others and creation differently. This does not serve merely as a model or a vision, but in Christ and through the Spirit we are enabled to participate in the self-giving and other-receiving love of the Triune God. This serves as a source for us to live lives of generosity, hospitality, responsibility and joy. 